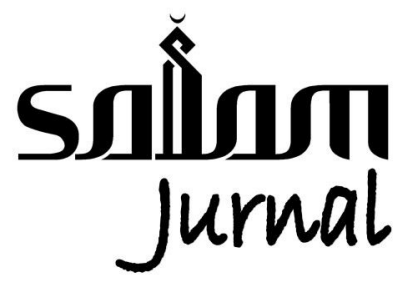

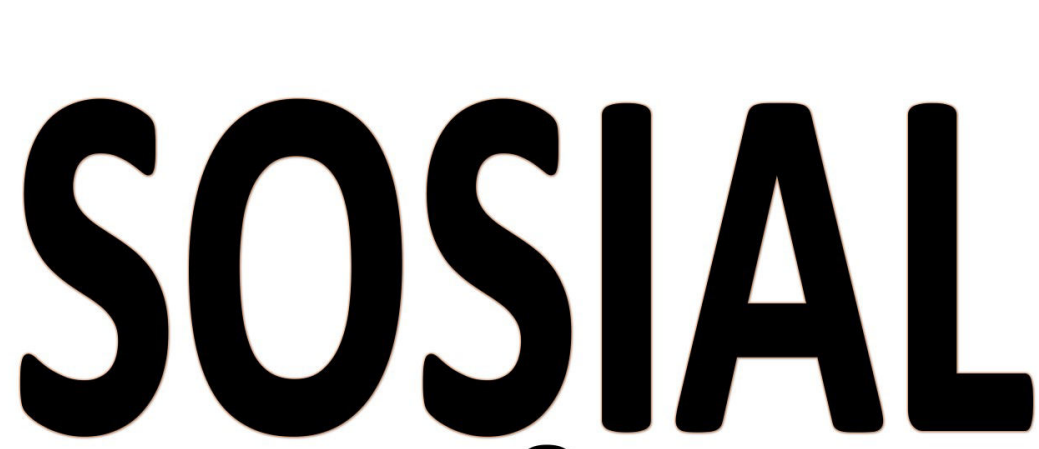

P-ISSN: 2356-1459 E-ISSN: $2654-9050$ Vol. 7 No. 4 (2020)
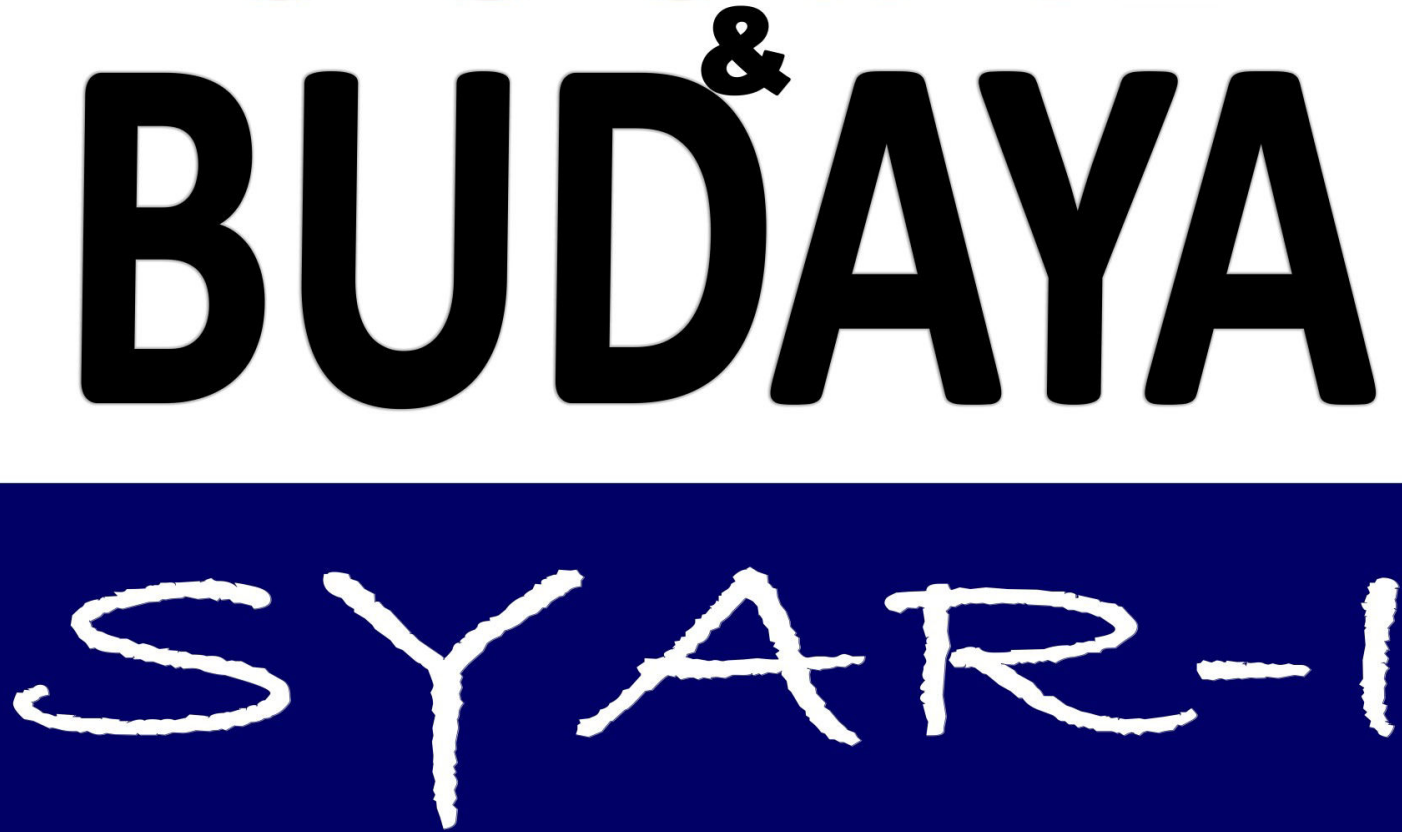

Pesona Tari sebagai Aset Pariwisata Budaya Indonesia

Pupitaning Wulan \& Warih Handayaningrum

Negosiasi Sosiologis Masyarakat Gresik dalam Seni Religi Hadrah

Agni Kusumawati \& Setyo Yanuartuti

Pemuliaan Islam Terhadap Kaum Wanita Dalam Perspektif Alquran dan Hukum Positif

Siti Ngainnur Rohmah

Accounts Payable (Qardh) in Islamic Law

Saprida, Choiriyah \& Melis

Kebijakan Pidana Dalam Pelanggaran Hak Cipta Di Indonesia

Yoyo Arifardhani

Alternatif Penyelesaian Sengketa sebagai Solusi Mewujudkan Asas Pemeriksaan Perkara -

"Sederhana, Waktu Singkat dan Biaya Murah"

Syafrida

Faktor Yang Mempengaruhi Nilai Perusahaan Dengan Corporate Social Responsibility Sebagai -

Variabel Moderating

Senja Nuansari 


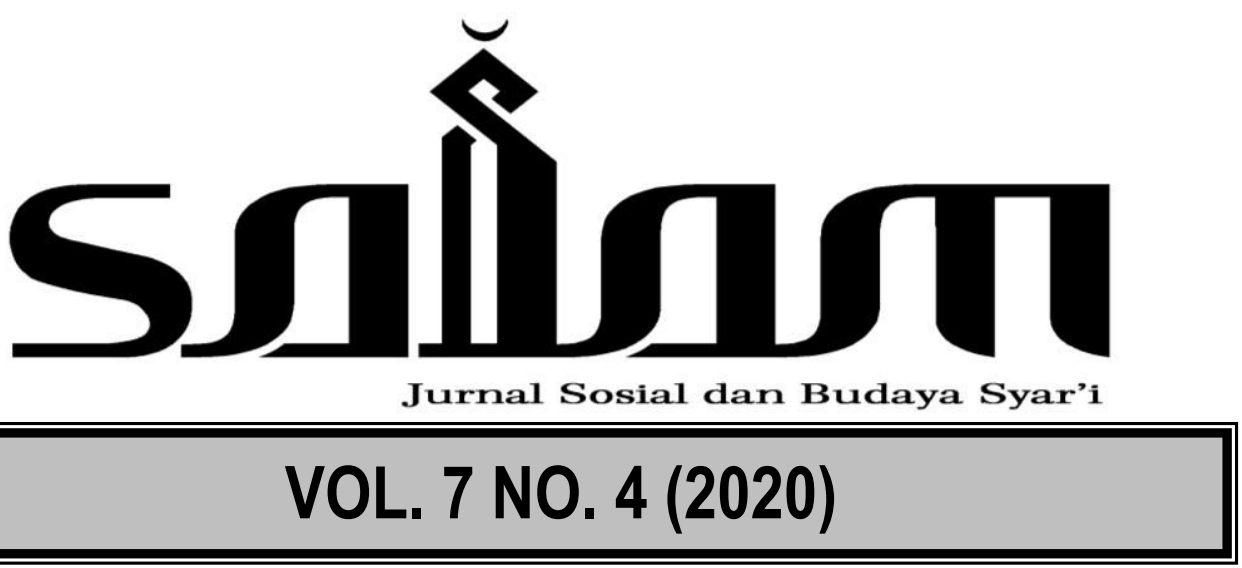

SALAM: Jurnal Sosial Budaya Syar-i (SJSBS) is an open access, and peer-reviewed journal. Our main goal is to disseminate current and original articles from researchers and practitioners on various contemporary social and sharia culture issues. SJSBS is published six times a year. It is nationally accredited by the Ministry of Research, Technology and Higher Education of the Republic of Indonesia (RISTEKDIKTI), No. 30/E/KPT/2019 (November 11, 2019). Submissions are open year-round. Before submitting, please ensure that the manuscript is in accordance with SJSBS's focus and scope and follows our author guidelines \& manuscript template.

SALAM: Jurnal Sosial Budaya Syar-i has become a CrossRef Member since year 2015. Therefore, all articles published by SALAM will have unique DOI number P-ISSN: 2356-1459 - E-ISSN: 2654-9050

\section{Reviewer}

Muhammad Amin Suma (UIN Syarif Hidayatullah Jakarta) A Salman Maggalatung (UIN Syarif Hidayatull ah Jakarta) Asep Saepudin Jahar (UIN Syarif Hidayatullah Jakarta) Ahmad Mukri Aji (UIN Syarif Hidayatullah Jakarta)

JM Muslimin (UIN Syarif Hidayatullah Jakarta)

Muhammad Munir (IIU Islamabad Pakistan)

Euis Amalia (UIN Syarif Hidayatullah Jakarta)

Tim Lindsey (Melbourne University Australia)

Raihanah Azahari (University Malaya Malaysia)

Ahmad Tholabi (UIN Syarif Hidayatullah Jakarta) Ahmad Hidayat Buang (University Malaya Malaysia)

\section{Editor In Chief} Erwin Hikmatiar

\section{Managing Editor}

Indra Rahmatullah

\section{Editors}

Muhammad Ishar Helmi

Mara Sutan Rambe

Nur Rohim Yunus

\section{Assistant to the Editors}

Imas Novita Juaningsih

Azizah Ratu Buana

\section{Alamat Redaksi}

Fakultas Syariah dan Hukum UIN Syarif Hidayatullah Jakarta

J1. Ir. H. Juanda 95 Ciputat Jakarta 15412 Telp. (62-21) 74711537, Faks. (62-21) 7491821 Website: http://journal.uinjkt.ac.id/index.php/salam, E-mail: jurnal.salam@uinjkt.ac.id 


\section{TABLE OF CONTENTS}

\section{3-298}

Pesona Tari sebagai Aset Pariwisata Budaya Indonesia

Pupitaning Wulan \& Warih Handayaningrum

\section{9-310}

Negosiasi Sosiologis Masyarakat Gresik dalam Seni Religi Hadrah

Agni Kusumawati \& Setyo Yanuartuti

\section{1-324}

Pemuliaan Islam Terhadap Kaum Wanita Dalam Perspektif Alquran dan Hukum Positif

Siti Ngainnur Rohmah

\section{5-334}

Accounts Payable (Qardh) in Islamic Law

Saprida, Choiriyah \& Melis

\section{5-352}

Kebijakan Pidana Dalam Pelanggaran Hak Cipta Di Indonesia

Yoyo Arifardhani

\section{3-370}

Alternatif Penyelesaian Sengketa sebagai Solusi Mewujudkan Asas

Pemeriksaan Perkara "Sederhana, Waktu Singkat dan Biaya Murah"

Syafrida

\section{1-394}

Faktor Yang Mempengaruhi Nilai Perusahaan Dengan Corporate Social Responsibility sebagai Variabel Moderating

Senja Nuansari 


\title{
Alternatif Penyelesaian Sengketa Sebagai Solusi Mewujudkan Asas Pemeriksaan Perkara "Sederhana, Waktu Singkat dan Biaya Murah" *
}

\author{
Syafrida ${ }^{1}$ \\ Universitas Tama Jagakarsa Jakarta \\ $\underline{10.15408 / \text { sjsbs.v7i4.15167 }}$
}

\begin{abstract}
Background to the problem "Alternative Dispute Resolution" (APS) is a dispute resolution agency or dissent which is resolved through an agreement procedure by the parties carried out outside the court by means of consultation, negotiation, mediation, conciliation or expert judgment. The settlement is based on good faith by ignoring litigation settlement through the District Court which takes a long time and is expensive, bound to formal procedures that must be implemented. This certainly contradicts the principle of civil procedural law "examination is as simple as possible, short time and low cost." The method used to write this article is Library Research using secondary data in the form of primary legal materials, secondary legal materials and tertiary legal materials relating to Alternative Dispute Resolution (APS). The research is normative juridical. The conclusion is that dispute resolution through alternative dispute resolution carried out in a manner that is carried out outside the court is based on good faith to reach an agreement, mutually beneficial is to realize the principle of hearing a simple "short time and low cost." While the superiority of resolution through Alternative Dispute Resolution (APS) is an examination based on the agreement of the parties, good faith, mutual benefit between the two parties, no one loses and wins, prevents hostility between the parties and closed examination.
\end{abstract}

Keywords: Alternative Dispute Resolution, Examination "simple, short time and low cost"

\begin{abstract}
Abstrak
Latar belakang masalah Alternatif Penyelesaian Sengketa (APS) adalah lembaga penyelesaian sengketa atau beda pendapat yang diselesaikan melalui prosedur kesepakatan oleh para pihak dilakukan di luar pengadilan dengan cara konsultasi, negosiasi, mediasi, konsiliasi atau penilaian ahli. Penyelesaian didasarkan itikad baik dengan mengenyampingkan penyelesaian secara litigasi melalui Pengadilan Negeri yang memakan waktu yang lama dan biaya yang mahal, terikat pada prosedur yang formal yang harus dilaksanakan. Hal ini tentu bertentangan asas hukum acara perdata "pemeriksaan sesederhana mungkin, waktu singkat dan biaya murah." Metode yang digunakan untuk menulis artikel ini adalah Penelitian Kepustakaan dengan menggunakan data sekunder berupa bahan hukum primer, bahan hukum sekunder dan bahan hukum tertier yang berkaitan dengan Alternatif Penyelesaian Sengketa (APS). Penelitian bersifat yuridis normatif. Kesimpulannya bahwa penyelesaian sengketa melalui alternatif penyelesaian sengketa yang dilakukan dengan cara yang dilakukan di luar pengadilan didasarkan pada itikad baik untuk mencapai kesepakatan, saling menguntungkan adalah untuk mewujudkan asas pemeriksaan perkara "sederhana waktu singkat dan biaya murah."
\end{abstract}

*Diterima: 18 Maret 2020, Revisi: 20 Maret 2020, Diterbitkan 4 April 2020.

${ }^{1}$ Syafrida adalah Dosen tetap Fakultas Hukum Universitas Tama Jagakarsa, Jakarta. 
Sedang keunggulan penyelesaian melalui Alternatif Penyelesaian Sengketa (APS) adalah pemeriksaan didasarkan kesepakatan para pihak, itikad baik, saling menguntungkan kedua belah pihak, tidak ada pihak yang kalah dan menang, mencegah permusuhan diantara para pihak dan pemeriksaan tertutup.

Kata Kunci: Alternatif Penyelesaian Sengketa, Pemeriksaan "sederhana, waktu singkat dan biaya murah"

\section{Pendahuluan}

Manusia adalah makhluk sosial, manusia tidak dapat hidup sendiri untuk memenuhi kebutuhan atau kepentingannya tersebut manusia membutuhkan orang lain. Interaksi yang dilakukan oleh manusia untuk memenuhi kebutuhannya atau kepentingannya tidak tertutup kemungkinan terjadinya suatu konflik atau sengketa. Oleh sebab itu diperlukan ketentuan untuk menyelesaikan sengketanya. Salah satu fungsi hukum dalam masyarakat adalah untuk menyelesaikan konflik. Istilah konflik Bahasa Inggiris: Conflict dan dispute, Bahasa Indonesia: conflict (konflik), dispute (sengketa). ${ }^{2}$

Sengketa yang terjadi antara hubungan antara orang perorangan termasuk dalam ruang lingkup hukum perdata. Dalam hukum kita dilarang keras untuk main hakim sendiri. Segala sengketa yang terjadi harus diselesaikan sesuai ketentuan hukum yang berlaku. Sengketa yang termasuk dalam ruang lingkup Hukum Perdata dapat diselesaikan dengan cara non litigasi (luar pengadilan) dan litigasi melalui pengadilan. Penyelesaian suatu sengketa perdata secara non litigasi dapat dilakukan melalui Alternatif Penyelesaian Sengketa (APS) dan arbitrase yang diatur dalam UndangUndang Nomor 30 Tahun 1999 tentang Arbitrase dan Alternatif Penyelesasain Sengketa.

Penyelesaian sengketa melalui Alternatif Penyelesaian Sengketa (APS) pertama kali muncul di Inggris Alternative Dispute Resolution (ADR) yang merupakan istilah yang pertama kali muncul di Amerika Serikat. ADR merupakan jawaban atas ketidakpuasan masyarakat Amerika Serikat terhadap sistem pengadilan yang berlaku di negaranya. Permasalahan yang muncul ketika itu penyelesaian sengketa melalui pengadilan memakan waktu yang lama, biaya yang mahal dan diragukan penyelesaiannya yang dapat memuaskan kepada para pihak. ADR dikembangkan oleh praktisi hukum maupun kalangan akademi sebagai proses penyelesaian sengketa yang lebih memberikan rasa keadilan. ${ }^{3}$

Pasal 1 angka 10 Undang-Undang Nomor 30 Tahun 1999 menyatakan: "Alternatif Penyelesaian Sengketa adalah lembaga penyelesaian sengketa atau beda pendapat melalui prosedur yang disepakati oleh para pihak yakni penyelesaian diluar pengadilan dengan cara konsultasi, negosiasi, mediasi, konsiliasi atau penilaian ahli."

Berdasarkan Pasal 1 angka 10 Undang-Undang Nomor 30 Tahun 1999 disimpulkan bahwa Alternatif Penyelesaian Sengketa (APS) adalah penyelesaian 2013, hlm 3 .

2 Rachmadi Usman, Pilihan Penyelesaian Sengketa di luar Pengadilan, PT Citra Aditya Bakti, Bandung

${ }^{3}$ Mas Achmad Santosa, Alternative Dispute Resolution (ADR) di bidang Lingkungan hidup, makalah disampaikan dalam Acara Forum Lingkungan Hidup tentang Alternative Dispute Resolutio (ADR) yang diselenggarakan oleh Tim Pakar Hukum Departemen Kehakiman, hlm.1 
sengketa atau beda pendapat diselesaikan diluar pengadilan (non litigasi) dilakukan dengan cara negosiasi mendiasi, konsiliasi atau penilaian ahli dengan mengutamakan musyawarah, didasarkan itikad baik para pihak untuk mencapai kesepakatan.

Salah satu asas dalam hukum acara perdata adalah "pemeriksaan sesederhana mungkin, waktu singkat dan bahaya murah", bahwa dalam pemeriksaan suatu sengketa atau beda pendapat dalam prosedur penyelesaiannya upaya dengan prosedur yang sesederhana mungkin dengan waktu yang singkat dan biaya yang murah. Untuk mewujudkan asas hukum dalam pemeriksaan sengketa (perdata) diperlukan penyelesaian sengketa melalui Alternatif Penyelesaian Sengketa (APS). Hal inilah yang menjadi latar belakang penulis untuk menulis artikel ini yang berjudul: Alternatif Penyelesaian Sengketa sebagai Upaya Mewujudkan Pemeriksaan Sengketa Secara "Sederhana, Waktu Singkat dan Biaya Murah."

\section{Metode Penelitian}

Metode yang digunakan untuk melakukan penelitian adalah Penelitian Kepustakaan dengan menggunakan data sekunder yang berupa bahan hukum primer, bahan hukum sekunder dan bahan hukum tertier yang berkaitan dengan Alternatif Penyelesaian Sengketa (APS). Data yang diperoleh dari hasil penelitian kepustakaan selanjutnya diolah secara sistematik ilmiah untuk menjawab rumusan malasah. Sedang tujuan penulisan untuk memberi pengetahuan kepada pembaca pemeriksaan sengketa melalui Alternatif penyelesaian Sengketa untuk mewujudkan pemeriksaan "sederhana, waktu singkat dan murah" dan untuk mengetahui keunggulan-keunggulan pemeriksaan melalui Alternatif Penyelesaian Sengketa (APS).

\section{Analisis dan Pembahasan}

\section{Pengertian dan Dasar Hukum Alternatif Penyelesaian Sengketa}

Dalam Kamus Hukum, membedakan antara Alternatif Penyelesaian Sengketa dengan ADR sebagai berikut: Alternatif Penyelesaian Sengketa adalah “Suatu pilihan penyelesaian sengketa yang dipilih melalui prosedur yang disepakati oleh para pihak yang bersengketa, sedangkan penyelesaian di luar pengadilan dapat dilakukan melalui beberapa pilihan yang disepakati oleh para pihak yang dapat dilakukan melalui konsultasi, negosiasi, mediasi, atau dengan mengunakan penilaian ahli."

ADR adalah "Suatu konsep yang meliputi berbagai bentuk pilihan penyelesaian sengketa selain proses peradilan yaitu melalui cara-cara yang sah menurut hukum, baik berdasarkan pendekatan consensus atau tidak.

Alternative Dispute Resolution yang selanjutnya disingkat ADR yang merupakan istilah asing. Dalam Bahasa Indonesia dikenal dengan beberapa istilah seperti, Pilihan Penyelesaian Sengketa (PPS), Mekanisme Alternatif Penyelesaian Sengketa (MAPS),

\footnotetext{
${ }^{4}$ M. Marwan dan Jimmy P, Kamus Hukum: Dictionary of Law Complete Edition, Reality Publisher, Surabaya, hlm. 39
} 
pilihan penyelesaian sengketa diluar pengadilan, dan mekanisme penyelesaian sengketa secara kooperatif. ${ }^{5}$

Undang-Undang Nomor 30 Tahun 1999 tentang Arbitrase dan Alternatif Penyelesaian Sengketa yang selanjutnya disebut UUAAPS, mengatur mengenai pilihan dalam penyelesaian sengketa secara musyawarah dari pihak yang bersengketa sebagaimana dinyatakan Pasal 1 angka 10 UUAAPS menyatakan: "Alternatif Penyelesaian Sengketa adalah proses penyelesaian sengketa yang dilakukan diluar pengadilan berdasarkan kesepakatan dari pihak yang bersengketa dengan mengenyampingkan penyelesaian sengketa secara litigasi di pengadilan. Penyelesaian sengketa dapat dilakukan dengan cara konsultasi, negosiasi, mediasi, konsiliasi atau penilaian ahli."

Dari beberapa uraian di atas disimpulkan bahwa, Alternatif Penyelesaian Sengketa adalah penyelesaian sengketa dilakukan di luar pengadilan secara kooperatif oleh pihak yang bersengketa untuk mencapai kedamaian atau kesepakatan tidak ada pihak yang dirugikan dan saling menguntungkan kepada pihak yang bersengketa. Alternatif Penyelesaian Sengketa (APS) merupakan penyelesaian sengketa diluar pengadilan berdasarkan kesepakatan para pihak dengan mengenyampingkan penyelesaian sengketa melalui proses litigasi. ${ }^{6}$

ADR merupakan penyelesaian sengketa dilakukan sendiri oleh pihak yang bersengketa dengan atau tanpa bantuan pihak ketiga. Pihak ketiga berperan membantu dalam penyelesaian sengketa atau beda pendapat dari pihak yang bersengketa. Penyelesaian sengketa melalui ADR yang dilakukan diluar pengadilan melalui pilihan sukarela dari pihak yang bersengketa. Penyelesaian sengeketa yang dilakukan melalui ADR hanya dapat ditempuh apabila para pihak sepakat sengketanya diselesaikan melalui pilihan alternatif penyelesaian sengketa.

Sengketa yang dapat diselesaikan melalui Alternatif Penyelesaian Sengketa pada umumnya adalah sengketa bidang perdata. Penyelesaian sengketa atau beda pendapat tersebut dilakukan secara langsung oleh para pihak dalam waktu 14 hari dan hasilnya dituangkan dalam bentuk tertulis (Pasal 6 angka 2). Jika penyelesaian yang dimaksud oleh Pasal 6 angka (2) tidak tercapai, maka atas kesepakatan tertulis para pihak, sengketa atau beda pendapat tersebut diselesaikan melalui bantuan seorang atau lebih penasehat ahli (Pasal 6 angka 3). Apabila dalam waktu 14 hari dengan bantuan seorang ahli atau mediator tidak tercapai kata sepakat, maka dapat menghubungi lembaga arbitrase atau lembaga Alternatif Penyelesaian Sengketa untuk menunjuk seorang mediator (Pasal 6 angka 4).

Mediator yang melakukan pemeriksaan harus memegang teguh kerahasiaan, hasil kesepakatan bersifat final dan mengikat untuk dilaksanakan dengan itikad baik dan didaftarkan di Pengadilan Negeri. Tujuan atau sasarannya dalam penyelesaian

\footnotetext{
${ }^{5}$ Suyud Margono, ADR (Alternative Dispute Resolution) dan Arbitrase), Ghalia Indonesia, 2000, hlm. $35-36$.

${ }^{6}$ Undang-Undang Nomor 30 Tahun 1999 tentang Alternatif Penyelesaian Sengketa, Pasal 1 angka 10.
} 
sengketa akan tercapai apabila didasarkan pada itikad baik dari pihak yang bersengketa atau beda pendapat dengan mengenyampingkan sengketa litigasi di pengadilan.

Pada umumnnya sengketa bidang Perdata dapat dilakukan melalui dua cara yaitu di pengadilan (litigasi) dan di luar pengadilan (non litigasi). Penyelesaian sengketa secara litigasi keberadaannya lebih dahulu dibandingkan penyelesaian sengketa secara non litigasi. Penyelesaian secara litigasi cenderung menimbulkan konflik, lebih lambat, belum mampu merangkul kepentingan pihak yang berperkara, biaya lebih mahal, tidak responsif dan menimbulkan permusuhan di antara pihak yang bersengketa.

Sebaliknya penyelesaian sengketa secara non litigasi (luar pengadilan) menghasilkan kesepakatan yang bersifat "win win solution", dijamin kerahasian sengketa para pihak, penyelesaian lebih cepat, dihindari kelambatan yang diakibatkan karena prosedural dan administratif, serta menyelesaikan masalah secara komprehensif dalam kebersamaan dan tetap menjaga hubungan baik, putusan tidak dipublikasikan. ${ }^{7}$

Penyelesaian sengketa di luar pengadilan pada umumnya terbatas pada perkaraperkara keperdataan dan dagang saja, sedangkan untuk perkara lainnya seperti pidana tetap diselesaikan melalui pengadilan. ${ }^{8}$ Di berbagai negara ADR sebagai jalan terobosan alternatif penyelesaian sengketa litigasi yang dapat menguras waktu, pikiran dan tenaga malah dapat menjerumuskan usaha ke arah kehancuran. ${ }^{9}$

\section{Macam-Macam Penyelesaian Alternatif Penyelesaian Sengketa Alternatif}

Penyelesaian sengketa luar pengadilan dapat dilakukan melalui arbitrase dan Alternatif Penyelesaian Sengketa sebagaimana yang diatur dalam Undang-Undang Nomor 30 Tahun 1999 tentang Alternatif Penyelesaian Sengketa dan Arbitrase yang dapat dilakukan dengan cara negosiasi, mediasi dan Konsiliasi atau penilaian ahli.

\section{a. Negosiasi}

Dalam bahasa sehari-hari istilah "negosiasi" sepadan dengan arti "berunding," "bermusyawarah" atau "bermufakat." Dalam Bahasa Inggris "negotitation" yang berarti perundingan. Orang yang melakukan perundingan dinamakan negosiator. ${ }^{10}$ Pengertian Negosiasi menurut Kamus Besar Bahasa Indonesia (KBBI) terdapat beberapa pengertian seperti berikut:

${ }^{7}$ Suyud Margono, ADR (Alternative Dispute Resolution) dan Arbitrase), hlm.5.

${ }^{8}$ Suyud Margono, ADR (Alternative Dispute Resolution) dan Arbitrase), hlm.5.

${ }_{9}$ M.Yahya Harahap, Beberapa Tinjauan Mengenai Sistem Peradilan dan Penyelesaian Sengketa, PT Citra Aditya Bakti, Bandung, 1997, hlm.280-281. Lihat: A.S. Maggalatung; A.M. Aji; N.R. Yunus. How The Law Works, Jakarta: Jurisprudence Institute, 2014. Lihat juga: A.M. Aji; N.R. Yunus. Basic Theory of Law and Justice, Jakarta: Jurisprudence Institute, 2018.

${ }^{10}$ Joni Emirzon, Alternatif Penyelesaian Sengketa diluar Pengadilan: Negosiasi, Mediasi, Konsiliasi dan Arbitrase, PT Gramedia Pustaka Utama, Jakarta, hlm. 144. 
1) Proses tawar menawar dengan jalan berunding untuk memberi atau menerima guna mencapai kesepakatan bersama antara satu pihak (kelompok atau oranisasi) dan pihak (kelompok atau organisasi) yang lain.

2) Penyelesaian sengketa secara damai melalui perundingan antara pihak-pihak yang bersengketa. ${ }^{11}$

Dalam Kamus Hukum: Dictionary of Law Complete Edition dinyatakan, negosiasi adalah proses tawar menawar dengan jalan berunding antara para pihak yang bersengketa untuk mencari kesepakatan bersama. ${ }^{12}$

Pasal 6 ayat (2) UUAAPS menyatakan Negosiasi adalah: "Penyelesaian atau beda pendapat melalui alternatif penyelesaian sengketa sebagaimana yang dimaksud ayat (1) diselesaikan dalam pertemuan langsung oleh para pihak dalam waktu paling lama 14 hari dan hasilnya ditungkan dalam kesepakatan tertulis."

\section{b. Mediasi}

Istilah "mediasi" berasal dari Bahasa Inggris "mediation" yang artinya penyelesaian sengketa yang melibatkan pihak ketiga sebagai penengah atau penyelesaian sengketa secara menengah. Pihak yang menengahinya dinamakan "mediator" atau orang yang menjadi penengah. Dalam Kamus Hukum Ekonomi ELIPS mediasi adalah salah satu alternatif penyelesaian sengketa di luar pengadilan dengan menggunakan jasa seorang mediator atau penengah, sama seperti konsiliasi. Mediator adalah penengah yaitu seorang yang menjalankan fungsi sebagai penengah terhadap pihak-pihak yang bersengketa dalam menyelesaikan sengketanya. ${ }^{13}$ Dalam Kamus Besar Bahasa Indonesia, Mediasi adalah proses pengikutsertaan pihak ketiga dalam menyelesaikan suatu perselisihan sebagai penasehat. Mediator adalah perantara atau penghubung, penengah bagi pihak yang bersengketa. ${ }^{14}$ Kamus Hukum: (Dictionary of Law Complete Edition), Mediasi adalah suatu proses penyelesaian sengketa secara damai yang melibatkan pihak ketiga untuk memberikan solusi yang dapat diterima oleh pihak yang besengketa. Pengikut sertakan pihak ketiga dalam penyelesaian sengketa antara dua pihak. ${ }^{15}$

Mediasi adalah proses penyelesaian sengketa antara para pihak dengan bantuan pihak ketiga (mediator) yang netral dan tidak memihak sebagai fasilitator guna

11 Tim Penyusunan Kamus Pusat Pembinaan dan Pengembangan Bahasa, Kamus Besar Bahasa Indonesia, Departemen Pendidikan Kebudayaan Republik Indonesia, Jakarta, 1988, hlm. 611

${ }_{12}$ M.Marwan dan Jimmy P, Kamus Hukum Dictionary of Law Complete Edition, Reality Publisher, Surabaya, 2009, hlm. 450.

${ }^{13}$ Tim Penyunting Kamus Hukum Ekonomi ELIPS, Kamus Hukum Ekonomi ELIPS, ELIPS Project, Jakarta, hlm.111.

${ }^{14}$ Tim Penyusun Kamus pusat Pembinaan dan Pengembangan Bahasa, Departemen Pendidikan Kebudayaan, Jakarta, 1988, hlm. 569.

${ }^{15}$ M. Marwan dan Jimmy P. Kamus Hukum Dictionary of Law Complete Edition, Reality Publishhar, Surabaya, hlm. 426. Lihat juga: Annissa Rezki, RR. Dewi Anggraeni, Nur Rohim Yunus, "Application of Civil Law Theory In the Termination of Custody of Adopted Children in Indonesia," Journal of Legal Research, Volume 1, No. 6 (2019). 
mencapai suatu kesepakatan yang tetap diambil oleh para pihak itu sendiri tidak oleh mediator. Mediasi penyelesaian sengketa dimana negosiasinya dibantu oleh pihak ketiga. Pihak ketiga bertindak untuk kepentingan kedua belh pihak. ${ }^{16}$

Pasal 6 ayat (3) UUAAPS meyatakan mediasi adalah: "Dalam hal sengketa atau beda pendapat sebagaimana yang dimaksud ayat (2) tidak dapat diselesaikan, maka atas kesepakatan tertulis para pihak, sengketa atau beda pendapat diselesaikan melalui bantuan seorang atau lebih penasehat ahli maupun melalui seorang mediator."

\section{c. Konsiliasi}

Konsiliasi adalah Penyelesaian Sengketa Alternatif (ADR) dimana para pihak yang berselisih menggunakan konsiliator yang bertemu dengan para pihak secara terpisah dan bersama-sama dalam upaya menyelesaikan perbedaan mereka. Mereka melakukan hal ini untuk meredakan ketegangan, meningkatkan komunikasi, menafsirkan masalah, mendorong para pihak untuk menemukan hasil yang dapat diterima. ${ }^{17}$

Kamus Bahasa Indonesia mengartikan konsiliasi adalah usaha mempertemukan kedua belah pihak yang berselisih untuk mencapai persetujuan dan menyelesaikan perselisihan. ${ }^{18}$

Menurut Oppenheim, konsiliasi adalah suatu proses penyelesaian sengketa dengan menyerahkan kepada suatu komisi orang-orang yang bertugas untuk menguraikan menjelaskan fakta-fakta dan biasanya setelah mendengar para pihak dan mengupayakan agar mereka mencapai kesepakatan, membuat usulan-usulan untuk menyelesaikan, namun keputusan itu tidak mengikat. ${ }^{19}$

\section{Ruang Lingkup Sengketa yang dapat diselesaikan melalui Alternatif Penyelesaian Sengketa}

Ruang lingkup sengketa yang dapat diselesaikan melalui alternatif penyelesaian sengketa berdasarkan Undang-Undang Nomor 30 Tahun 1999 adalah sengketa hukum perdata dan hukum dagang yang dapat diselesaikan melalui perdamaian berdasarkan kesepakatan dari pihak. Apabila sengketa perdata atau bidang hukum dagang tidak dapat diselesaikan melalui perdamaian, maka diselesaikan melalui litigasi di pengadilan. Penyelesaian sengketa melalui alternatif penyelesaian akan dapat dicapai apabila didasarkan pada itikad, baik dari para pihak yang bersengketa dengan mengenyampingkan penyelesaian sengketa melalui pengadilan.

${ }^{16}$ I.Made Widnyata, Alternatif Penyelesaian Sengketa dan Arbitrase, Fikahati Aneska, Jakarta, 2014, hlm. 116.

${ }^{17} \mathrm{http}: / /$ en.mwikipedia.org/wiki/ conciliation, diakses Kamis tanggal 19 maret 2020, pukul 18.00.

${ }^{18}$ Kamus Bahasa Indonesia, Departemen Pendidikan dan Kebudayaan dan Kebudayaan, Jakarta, 1988, hlm 457

${ }^{19}$ Huala Hadolf dan Chandrawulan, Masalah-Masalah Hukum dalam Perdagangan Internsional, PT Rjagrafindo Persada, Jakarta, hlm 186. 


\section{Alternatif Penyelesaian Sengketa mewujudkan Pemeriksaan "Sederhana, Waktu Singkat dan Biaya Murah"}

Pasal 1 angka 10 Undang-Undang Nomor 30 Tahun 1999 menyatakan: "Alternatif Penyelesaian Sengketa adalah lembaga penyelesaian sengketa atau beda pendapat melalui prosedur yang disepakati oleh para pihak yakni penyelesaian diluar pengadilan dengan cara konsultasi, negosiasi, mediasi, konsiliasi atau penilaian ahli." Berdasarkan Pasal 1 angka 10 Undang-Undang Nomor 30 Tahun 1999 dapat disimpulkan, bahwa penyelesaian sengketa melalui alternatif penyelesaian sengketa adalah penyelesaian sengketa yang disepakati oleh para pihak dilakukan diluar pengadilan berdasarkan konsultasi, negosiasi, mediasi konsiliasi atau penilaian ahli. Penyelesaian sengketa melalui alternatif penyelesaian sengketa dapat dicapai apabila didasarkan pada itikad baik para pihak, para pihak kooperatif untuk menyelesaikan masalahnya dan pihak ketiga sebagai mediator berperan aktif untuk memberikan masukan atau usulan untuk mengakhiri sengketa berdasarkan kesepakatan. Mengenyampingkan sengketa litigasi dan sengketa berada dalam lingkup hukum perdata atau hukum dagang yang dapat diselesaikan secara mediasi, musyawarah, perdamaian yang didasarkan pada itikad para pihak, sehingga didapat penyelesaian berdasarkan kesepakatan yang saling menguntungkan kepada pihak yang bersengketa.

\section{a. Negosiasi}

Para pihak yang bersengketa, secara langsung melakukan perundingan atau tawar menawar, sehingga menghasilkan kesepakatan secara bersama. Pihak yang bersengketa sudah tentu telah melakukan diskusi atau bermusyawarah sedemikian rupa agar hak-hak dan kepentingan para pihak terakomodir menjadi kepentingan atau kebutuhan bersama dari pihak yang bersengketa. Pada umumnya kesepakatan bersama dari pihak yang bersengketa merupakan hasil negosiasi dituangkan dalam bentuk tertulis.

Kesepakatan bersama dilakukan oleh para pihak atas dasar kerjasama yang lebih harmonis dan kreatif. Penyelesaian sengketa didasarkan pada pertemuan langsung oleh para pihak dilakukan dalam waktu paling lama 14 hari sejak negosiasi (perundingan) dilakukan oleh para pihak, dan para pihak sudah harus mengambil putusan yang dituangkan dalam bentuk kesepakatan tertulis.

Negosiasi adalah proses penyelesaian sengketa yang berlangsung secara sukarela antara pihak- pihak yang bersengketa yang mempunyai masalah atau kasuskasus dengan cara melakukan tatap muka secara langsung untuk memperoleh kesepakatan yang dapat diterima oleh kedua belah pihak. ${ }^{20}$ Negosiasi pada umumnnya digunakan untuk kasus yang sifatnya sederhana tidak terlalu pelik, dimana para pihak yang beritikad baik secara bersama memecahkan masalahnya. Negosiasi dilakukan jika komunikasi yang dilakukan oleh para pihak berjalan dengan baik, masih ada saling hlm. 80 .

\footnotetext{
${ }^{20}$ I.Made Widnyata, Alternatif Penyelesaian Sengketa dan Arbitrase, Fikahati Aneska, Jakarta, 2014,
} 
percaya dan ada keinginan untuk mencapai kesepakatan, serta untuk menjalin hubungan yang baik. ${ }^{21}$

Negosiasi merupakan penyelesaian sengketa yang paling umum. Bernegosiasi sudah merupakan bagian dari aktifitas kita dalam kehidupan sehari hari. Negosiasi merupakan sarana yang paling banyak digunakan dan yang paling efektif. Penyelesaiannya tidak win-lose tapi win-win, penyelesaian melalui negosiasi dipandang sebagai cara penyelesaian yang paling memuaskan kepada para pihak. ${ }^{22}$

Penyelesaian secara negosiasi paling cocok dilakukan di Indonesia untuk pengusaha kecil, menengah yang pada umumnya mereka dalam berbisnis tidak terlalu menggunakan kontrak. Kalau ada permasalahan mereka berupaya untuk menyelesaikan secara baik-baik dan kekeluargaan. Jika penyelesaian sengketa melalui negosiasi tidak tercapai barulah ditempuh jalur lain seperti mediasi, konsiliasi, arbitrase atau litigasi.

Keunggulan penyelesaian sengketa melalui negosiasi dibandingkan melalui litigasi adalah: biaya murah karena tidak melibatkan pihak ketiga, tidak dilakukan secara formal, karena hanya dilakukan oleh pihak yang berperkara atau wakilnya, penyelesaian sengketa dilakukan sendiri oleh para pihak, mencegah terjadi permusuhan diantara para pihak yang bersengketa, menjaga hubungan yang baik, bersifat pribadi dan sukarela dan penyelesaian memakan waktu yang cepat dibandingkan jalur litigasi.

Kelemahan Negosiasi, taktik salah satu pihak agar pihak lain menunda gugatan secara hukum dan tidak ada jaminan bahwa para pihak akan melaksanakan kewajiban terhadap apa yang telah disepakati. ${ }^{23}$

Pedoman dalam melakukan Negosiasi adalah sebagai berikut:

1. Mendegarkan pihak lain dengan seksama, penuh kesabaran walaupun kita tidak setuju dengan apa yang disampaikannya;

2. Mempelajari informasi penting dari pihak lain dan berpikir secara positif;

3. Hindari serangan yang bersifat pribadi dan pusatkan perhatian pada pokok permasalahan;

4. Cara penyelesaian yang saling menguntungkan dan yakinkan bahwa penyelesaian itu mudah dan dipahami oleh kedua belah pihak. ${ }^{24}$

Kendala yang dihadapi oleh para pihak dalam bernegosiasi adalah masing masing pihak yang bersengketa tetap bertahan pada posisi tawaran pertama, saling mempertahankan hak-hak dan kepentingan masing-masing. Jika tahap pertama (negosiasi) tidak tercapai masuk para pihak dapat lanjut pada tahap kedua yaitu mediasi. Pasal 6 ayat (3) UUAAPS menyatakan apabila negosiasi tidak tercapai para pihak dapat menempuh penyelesaian secara mediasi.

\footnotetext{
${ }^{21}$ Khotibul Uman, Penyelesaian Sengketa diluar Pengadilan, Pustaka Yustisia, Yogyakarta, hlm.10.

${ }^{22} \mathrm{Ibid}$.

${ }^{23}$ Op.cit, hlm. 86.

${ }^{24}$ Ibid. hlm. 87-88.
} 
Penyelesaian secara negosiasi adalah bentuk penyelesaian sengketa yang paling sederhana karena tidak melibatkan pihak lain, menghemat waktu karena penyelesaian didasarkan pada itikad baik dari para pihak untuk menyelesaikan sengketanya. Biaya lebih murah karena tidak mengeluarkan biaya untuk honor pihak ketiga dan waktu lebih cepat tentu saja akan mengemat biaya proses pemeriksaan.

Berdasarkan hal-hal yang disebutkan diatas dapat disimpulkan bahwa penyelesaian sengketa dengan cara negosiasi sejalan dengan asas pemeriksaan sengketa perdata yaitu pemeriksaan sederhana, waktu singkat dan biaya murah. Selain itu juga akan mencegah betumpuk-tumpuknya perkara di pengadilan.

\section{b. Mediasi}

Mediasi adalah cara penyelesaian sengketa di luar pengadilan melalui alternatif penyelesaian sengketa yang melibatkan pihak ketiga yang bersifat netral dan tidak memihak. Pihak ketiga tersebut dinamakan "mediator" atau "penengah" yang tugasnya hanya membantu para pihak yang bersengketa dalam menyelesaikan masalahnya dan tidak mempunyai kepentingan pribadi dan kewenangan untuk mengambil keputusan, karena keputusan tetap di tangan pihak yang bersengketa. Mediator dalam hal ini bertindak sebagai fasilitator yang dapat mengkafer kepentingan kedua belah pihak secara adil dan tepat.

Penyelesaian sengketa melalui mediasi diharapkan dapat mencapai titik temu dalam penyelesaian masalah atau sengketa yang dihadapi oleh para pihak. Hasil kesepakatan selanjutnya dituangkan dalam kesepakatan bersama yang dibuat dalam bentuk tertulis yang ditandatangani oleh para pihak dan mediator. Pengambilan keputusan tidak berada di tangan mediator, tetapi berada di tangan pihak yang bersengketa yang memutuskan. Mediator hanya berfungsi memberikan saran-saran atau usulan-usulan kepada para pihak dan usulan atau saran yang diberikan oleh mediator tidak mengikat kepada para pihak.

Dalam hal tercapainya kesepakatan berdasarkan Pasal 6 ayat (7 dan 8) UndangUndang Nomor 30 Tahun 1999 kesepakatan yang telah diraih oleh pihak yang bersengketa dibuat tertulis adalah final, mengikat para pihak untuk dilaksanakan dengan itikad baik dan wajib didaftarkan untuk waktu paling lama 30 hari sejak penandatanganan. Kesepakatan dalam alternatif penyelesaian sengketa wajib dilaksanakan paling lambat 30 hari setelah dilakukan pendaftaran kesepakatan di Pengadilan Negeri. Dengan dilakukan pendaftaran kesepakatan di Pengadilan Negeri akan menjadi kesepakatan yang berkekuatan eksekutorial dapat dilaksanakan secara paksa.

Pendaftaran hasil kesepakatan yang dimaksud adalah dilakukan dengan cara mengajukan gugatan kepada pihak lawan dalam perjanjian mediasi (kesepakatan perdamaian) di Pengadilan Negeri berwenang. Dengan dilakukannya pendaftaran terciptalah suatu akta perdamaian yang mempunyai kekuatan eksekutorial. Kesepakatan mediasi yang tidak didaftarkan di Pengadilan Negeri sama dengan perjanjian biasa yang mengikat para pihak berdasarkan Pasal 1338 KUHPerdata jo asas 
pacta sunt servanda. Perjanjian yang dibuat oleh para pihak merupakan undang-undang bagi yang membuatnya. ${ }^{25}$ Kesepakatan perdamaian yang tidak didaftar yang hanya mengikat berdasarkan Pasal 1338 KUHPerdata ini tidak mempunyai kekuatan eksekutorial dan sengketanya suatu saat di kemudian hari dapat diajukan kembali kembali oleh pihak yang bersengketa melalui pengadilan.

Peranan Mediator dalam suatu sengketa adalah; 1). Membantu para pihak dalam melakukan negosiasi; 2). Membantu para pihak melakukan komunikasi yang efektif dan produktif; 3). Membantu para pihak untuk menetapkan prioritas pokok sengketa yang akan diselesaikan; 4). Menfasilitasi para pihak agar dapat memperkecil kesenjangan yang ada diantara mereka; 5). Membantu para pihak bersama-sama memperkecil kesenjangan diantara mereka untuk mencapai damai; 6). Memilah-milah permasalahan yang dihadapi agar pertemuan dapat berlangsung; 7). Memberikan ide-ide terhadap permasalahan yang dihadapi oleh para pihak; 8). Membantu mengurangi rasa permusuhan diantara para pihak dan mendorong agar terjadinya kerjasama; 9). Membantu para pihak dalam menciptakan menganalisis pilihan penyelesaian; 10). Membantu para pihak dalam menuangkan penyelesaian dalam bentuk kesepakatan tertulis; 11). Membantu, memantau pelaksanaan kesepakatan. ${ }^{26}$

Seorang mediator harus mempunyai kemampuan untuk dapat menyelesaian sengketa serta mempunyai karakter yang baik. Kemampuan yang harus dimiliki seorang mediator adalah sebagai berikut: 1). keterampilan mendengar; 2). kemampuan mengenali masalah; 3). kesabaran; 4). netral; 5). kemampuan mendekatkan para pihak; 6). kemampuan untuk meyakinkan; 7). kemampuan membuat ringkasan; 8). kegigihan; 9). kemampuan menganalisis; 10. kreatifitas; 11). kemampuan menjaga kerahasiaan. ${ }^{27}$

Seorang mediator harus mempunyai karakter yang baik adalah sebagai berikut: 1). bisa dipercaya; 2). tidak berpihak dan tidak memutuskan; 3). pendengar yang baik; 4). bersungguh-sungguh dan mempunyai empati yang tinggi; 5). kreatif; 6). bijaksana dan pandai; 7). optimis dan bersemangat; 8). fleksibel; 9). gigih; 10). pandai mengeluarkan pikiran; 11). memiliki kemampuan melakukan investigasi; 12). analisis. ${ }^{28}$

Penyelesaian sengketa melalui mediasi berakhir apabila; 1). Para pihak setiap saat bebas untuk melakukan penarikan diri. Penarikan diri tidak menghilangkan keharusan untuk mengeluarkan biaya dan segala sesuatu yang telah disetujui selama diskusi-diskusi; 2). Jika mediasi berjalan sukses, para pihak menanda tangani suatu dokumen; 3). Jika mediasi tidak berhasil tahap pertama, maka para pihak menunda sementara mediasi, dan dapat melanjutkan mediasi baru dengan diskusi baru.

Pemeriksaan yang melalui mediasi yang melibatkan pihak ketiga sebagai mediator akan mempercepat proses pemeriksaan perkara, karena pihak ketiga sebagai mediator berperan membantu memberikan masukan kepada pihak yang bersengketa, netral, tidak memihak, tidak punya kepentingan pribadi terhadap sengketa. Hal ini

${ }_{25}$ R. Subekti dan R Tjitrosudibio, Kitab Undang-Undang Hukum Perdata, PT Radnya Paramita, Jakarta, 2003, hlm. 342.

${ }^{26}$ 1bid, hlm. 19-120.

${ }_{27}$ Ibid. hlm 127-128.

${ }^{28}$ Ibid, hlm 128-129 
tentu akan menyederhanakan pemeriksaan, proses lebih cepat dan biaya lebih murah. Pemeriksaan sengketa dengan cara mediasi sama dengan negosiasi adalah suatu pemeriksaan non litigasi yang sesuai asas hukum acara perdata "pemeriksaan sederhana, waktu singkat dan biaya murah." Pemeriksaan sederhana karena proses pemeriksaan tidak terikat kepada aturan yang bersifat formal seperti yang berlaku di pengadilan. Proses pemeriksaan berdasarkan sukarela dari pihak yang bersengketa dan mengenai prosedur, waktu dan tempat pemeriksaan diserahkan kepada para pihak untuk dapat menentukan sendiri berdasarkan kesepakatan, itikad baik dan tidak bertentangan Undang-Undang Nomor 30 Tahun 1999 tentang Alternatif Penyelesaian Sengketa.

\section{c. Konsiliasi}

Penyelesaian sengketa dengan cara konsiliasi adalah penyelesaian sengketa yang dilakukan di luar pengadilan yang dibantu oleh pihak ketiga yang netral untuk memberikan masukan-masukan terhadap masalah yang dihadapi oleh para pihak. Usulan atau masukan dari pihak ketiga tidak mengikat kepada pihak yang bersengketa. Konsiliator berusaha agar sengketa yang dihadapi oleh para pihak dapat diselesaikan melalui musyawarah untuk mencapai kesepakatan. Konsiliator bertindak aktif kepada para pihak untuk dapat menyelesaikan atau mengakhiri sengketanya. Konsiliator mencari jalan tengah dalam penyelesaian sengketa yang dapat diterima oleh kedua belah pihak.

Kesepakatan atau perdamaian yang dicapai dalam penyelesaian sengketa melalui konsiliasi merupakan perjanjian yang harus ditaati oleh kedua belah pihak. Semua informasi yang diperoleh selama pemeriksaan akan dirahasiakan. Penyelesaian sengketa dilakukan dengan melakukan perundingan dengan mengidentifikasi masalah, mendiskusikan masalah, memahami kebutuhan para pihak untuk mencapai kesepakatan. Penyelesaian lebih singkat, tidak terikat dengan aturan yang formal sebagaimana pemeriksaan yang dilakukan di pengadilan

Seorang konsiliator yng membantu para pihak yang bersengketa harus netral, aktif dalam membantu para pihak dengan memberikan masukan-masukan dan usulanusulan untuk mencapai kesepakatan. Konsiliator tidak berwenang untuk memberikan keputusan selama perundingan berlangsung. Konsiliator membantu para pihak untuk mencapai kesepakatan dalam rangka untuk mengakhiri sengketa. Konsiliator hanya membantu memberi masukan dan usulan-usulan dan keputusannya tidak mengikat terhadap para pihak.

Penyelesaian sengketa melalui konsiliasi dapat mewujudkan pemeriksaan secara sederhana, waktu singkat dan biaya murah asal pemeriksaan didasarkan pada itikad baik dari para pihak untuk sepakat menyelesaikan sengketanya.

Berdasarkan uraian diatas dapat disimpulkan, bahwa penyelesaian sengketa melalui konsiliasi dilakukan di luar pengadilan, dibantu pihak ketiga sebagai konsiliator yang aktif memberi masukan dan usulan untuk penyelesaian atau mengakhiri sengketa 
secara musyawarah untuk mencapai kesepakatan dalam rangka mewujudkan asas pemeriksaan perkara secara sederhana, waktu singkat dan biaya murah.

\section{d. Arbitrase}

Pasal 1 angka 1 Undang-Undang Nomor 30 Tahun 1999 tentang Arbitrase dan Alternatif Penyelesaian Sengketa menyatakan arbitrase adalah: "Cara penyelesaian suatu sengketa perdata di luar peradilan umum yang didasarkan perjanjian arbitrase yang dibuat secara tertulis oleh para pihak yang bersangkutan." Sengketa dapat diselesaikan melalui arbitrase hanyalah sengketa yang dikuasai secara penuh oleh pihak yang bersengketa atas dasar kesepakatan. Apabila penyelesaian sengketa melalui pilihan penyelesaian sengketa tidak dapat dicapai, maka para pihak berdasarkan kesepakatan secara tertulis dapat mengajukan usaha penyelesaiannya melalui arbitrase atau arbitrase ad-hoc.

Penyelesaian sengketa melalui arbitrase dilakukan paling lama 180 hari sejak arbiter terbentuk. Pelaksanaan pemeriksaan dilakukan berdasarkan Undang-Undang Nomor 30 Tahun 1999. Sebelum sebelum sengketa diselesaikan melalui arbitrase, para pihak yang bersengketa sepakat sengketanya diselesaikan melalui arbitrase. Kesepakatan para pihak dituangkan dalam bentuk perjanjian arbitrase yang dapat dibuat secara tertulis sebelum atau setelah terjadinya sengketa. Jika para pihak tidak membuat perjanjian arbitrase, maka sengketanya diselesaikan melalui arbitrase.

Sengketa yang dapat diselesaikan melalui arbitrase adalah sengketa di bidang perdagangan dan mengenai hak yang menurut hukum dan peraturan perundangundangan dikuasai sepenuhnya oleh pihak yang bersengketa (Pasal 5 ayat (1). Sengketa yang tidak dapat diselesaikan melalui arbitrase adalah sengketa yang menurut peraturan perundang-undangan tidak dapat diselesaikan melalui perdamaian (Pasal 5 ayat 2). Penyelesaian melalui arbitrase dilakukan dengan mengenyampingkan penyelesaian secara litigasi di Pengadilan Negeri. Perkara yang sudah diselesaikan melalui arbitrase tidak boleh lagi untuk diajukan ke Pengadilan Negeri karena putusan arbitrase bersifat final dan mengikat. Perjanjian arbitrase mengikat para pihak berdasarkan Pasal 1320 KUHPerdata. Pengadilan Negeri wajib menolak atau tidak akan campur untuk menyelesaikan sengketa yang telah ditetapkan melalui arbitrase, kecuali dalam hal-hal tertentu yang ditentukan dalam undang-undang .

Penyelesaian sengketa melalui arbitrase yang sudah ditentukan jangka waktunya yaitu 180 hari, memakan waktu yang lebih cepat dibandingkan penyelesaian sengketa secara litigasi melalui pengadilan yang dapat menyita waktu yang lama dan biaya yang mahal. Oleh karena itu, penyelesaian sengketa melalui arbitrase sudah ditentukan waktunya yaitu 180 hari, para pihak dapat memilih berdasarkan kesepakatan berkaitan prosedur penyelesaian, tempat dan waktu pemeriksaan. Hal ini tentu lebih menyederhanakan proses pemeriksaan dibandingkan penyelesaian melalui litigasi. Hal ini merupakan salah satu upaya mewujudkan pemeriksaan perkara sederhana dan waktu singkat. Berkaitan dengan biaya lebih mahal karena sengketa yang diselesaikan melalui arbitrase diselesaikan oleh arbiter yang ahli pada bidangnya. 
Penyelesaian sengketa melalui arbitrase banyak digunakan oleh pelaku usaha menengah keatas.

\section{Keunggulan Penyelesaian Sengketa Melalui ADR}

Keungggulan penyelesaian sengketa melalui alternatif penyelesaian sengketa adalah lebih efisien atau efektif, lebih cepat, lebih murah dibandingkan penyelesaian sengketa melalui pengadilan, karena menghasilkan kesepakatan yang diterima oleh kedua belah pihak. Para pihak dapat mengatur prosedur, tempat dan waktu penyelesaian sengketa dan pemeriksaan dan putusan sifatnya tertutup hanya diketahui pihak yang bersengketa tidak dipublikasikan. Bagi suatu perusahaan hal ini sangat menguntungkan karena akan menjaga nama baik dari perusahaan.

Penyelesaian sengketa di luar pengadilan (Alternative dispute resolution) atau $A D R)$ hanya terbatas terhadap perkara keperdataan dan dagang. Sedangkan perkara pidana harus melalui pengadilan. Penyelesaian secara ADR merupakan terobosan dari kelemahan penyelesaian sengketa melalui pengadilan yang memakan waktu yang lama, biaya yang mahal dan hakim memutus dengan putusan yang dikalahkan dan yang dimenangkan, sehingga dapat menimbulkan permusuhan di antara pihak yang berperkara.

Alternatif pilihan penyelesaian sengketa yang merupakan penyelesaian sengketa yang dilakukan secara non litigasi sebagaimana yang disebutkan di atas memiliki keunggulan jika dibandingkan penyelesaian sengketa yang dilakukan melalui pengadilan (Litigasi). Keunggulan penyelesaian sengketa melalui alternatif penyelesaian sengketa adalah dari proses pemeriksaan tidak terikat pada aturan yang bersifat formal. Para pihak yang bersengketa secara sukarela bersepakat memilih cara penyelesaian sengketa di luar pengadilan yang dapat dilakukan melalui negosiasi, mediasi dan konsiliasi atau penilaian ahli.

Cara penyelesaian sengketa di luar pengadilan yang diatur dalam Undangundang Nomor 30 Tahun 1999 tentang Arbitrase dan Alternatif Penyelesaian Sengketa, bahwa para para pihak secara sukarela dan sepakat memilih cara penyelesaian melalui pilihan alternatif penyelesaian sengketa. Penyelesaian didasarkan pada itikad baik para pihak untuk menyelesaikan masalah berdasarkan kesepakatan yang dapat mengkafer kepentingan pihak yang bersengketa yang saling menguntungkan, tidak ada yang kalah dan yang menang, sehingga mencegah terjadinya permusuhan diantara pihak yang bersengketa.

Negosisi sebagai salah satu cara penyelesaian sengketa secara non litigasi adalah cara paling sederhana dibandingkan cara mediasi, konsiliasi dan arbitrase, karena penyelesaian sengketa tidak melibatkan pihak ketiga. Pemeriksaan secara negosiasi hanya melibatkan pihak yang bersengketa secara langsung tidak melibatkan pihak lain. Pemeriksaan melalui negosiasi akan tercapai apabila didasarkan kepada itikad baik dari pihak dan proaktifnya para pihak untuk menyelesaikan masalahnya. Pemeriksaan dapat dilakukan kapan saja dan dimana saja berdasarkan kesepakatan para pihak. Keunggulan penyelesaian sengketa melalui negosiasi adalah prosedur lebih sederhana 
karena tidak melibatkan pihak ketiga. Proses pemeriksaan lebih cepat tergantung itikad dari pihak yang bersengketa. Prosedur yang sederhana tentu waktu pemeriksaan lebih cepat dan biaya lebih murah. Pemeriksaan berdasarkan kesepakatan hasil yang didapat win-win solution yang saling menguntungkan kepada pihak yang bersengketa, tidak ada yang kalah dan yang menang. Pemeriksaan tertutup tidak diketahui oleh publik, hal ini sangat menguntungkan kepada pihak yang bersengketa. Pihak yang bergerak dalam bidang bisnis akan tetap terjaga nama baik dari perusahaan.

Itikad baik dari para pihak untuk menyelesaian sengketanya sangat menentukan untuk tercapainya penyelesaian melalui negosiasi tercapai. Para pihak aktif dalam bernegosiasi untuk mencapai kesepakatan yang didukung oleh itikad baik untuk menyelesaikan sengketa secara musyawarah, mufakat. Agar hasil penyelesaian secara negosiasi mempunyai kekuatan eksekutorial dapat dilaksanakan secara paksa apabila hasil kesepakatan yang telah dituangkan dalam bentuk tertulis didaftarkan ke Pengadilan Negeri yang berwenang dengan mengajukan gugatan ke Pengadilan.

Sebaliknya apabila hasil kesepakatan berdasarkan penyelesaian sengketa melalui negosiasi tidak didaftarkan ke pengadilan, maka hasil kesepakatan yang dituangkan dalam bentuk tertulis hanya merupakan perjanjian biasa, tidak mempunyai kekuatan eksekutorial dan tidak tertutup kemungkinan dapat diajukan kembali oleh pihak yang bersengketa melalui pengadilan.

Apabila pemeriksaan melalui negosiasi tidak tercapai kesepakatan, maka pihak yang bersengketa dapat menempuh penyelesaian sengketa melalui mediasi yang dilakukan dengan melibatkan pihak ketiga sebagai mediator. Seorang yang ditunjuk sebagai mediator dalam suatu sengketa harus bersifat netral, tdak memihak dan tidak punya kepentingan pribadi terhadap sengketa. Mediator ditunjuk oleh para pihak berdasarkan kesepakatan. Apabila mediator yang diajukan oleh salah satu pihak tidak disetujui oleh pihak lain, maka tidak dapat diangkat sebagai mediator. Mediator berperan memberi saran atau masukan terhadap masalah yang sedang dihadapi oleh pihak yang sengketa. Saran atau masukan yang diberikan oleh pihak ketiga tidak mengikat kepada pihak yang bersengketa. Pihak yang bersengketa dapat menerima atau menolak saran yang diberikan oleh mediator. Keputusan tetap di tangan pihak yang bersengketa.

Keunggulan penyelesaian melalui mediasi, karena melibatkan pihak ketiga yang bersifat netral diharapkan dapat membantu para pihak lebih cepat dalam menyelesaian sengketa dan dapat mengkaver kepentingan kedua belah pihak yang sedang bersengketa. Penyelesaian tidak terbuka untuk umum hanya diketahui oleh pihak yang bersengketa dan pihak ketiga dan pihak ketiga juga tidak boleh mempublikasikan sengketa yang sedang dihadapi oleh pihak yang bersengketa.

Selanjutnya apabila penyelesaian secara negosiasi, mediasi tidak tercapai para pihak dapat menempuh penyelesaian melalui konsiliasi. Penyelesaian sengketa melalui konsiliasi dibantu oleh pihak ketiga sebagai konsiliator. Konsiliator adalah pihak ketiga yang ahli di bidangnya. Keungggulan sengketa diselesaikan melalui konsiliasi adalah karena sengketa dibantu oleh pihak ketiga yang ahli dalam bidangnya yang diharapkan dapat memberikan penyelesaian yang tepat, cepat dan dapat memenuhi kepentingan 
kedua pihak yang bersengketa. Pemeriksaan dilakukan secara tertutup tidak dipublikasikan dan hanya diketahui oleh pihak yang bersengketa dan konsiliator. Bagi pihak yang bergerak dalam bisnis adalah suatu keuntungan karena bisnis tidak terganggu, perusahaan tetap terjaga nama baiknya.

Penyelesaian sengketa melibatkan pihak ketiga yang ahli dalam bidangnya tentu saja para pihak harus mengeluarkan biaya untuk membayar honor konsiliator. Berapa besarnya biaya yang harus dibayar tergantung kepada kesepakatan para pihak dengan konsiliatornya.

Selanjutnya apabila penyelesaian sengketa melalui alternatif penyelesaian sengketa tidak tercapai, maka para pihak dapat menempuh proses pemeriksaan melalui arbitrase. Penyelesaian sengketa melalui arbitrase dilakukan berdasarkan kesepakatan kedua belah pihak bahwa sengketanya diselesaikan melalui arbitrase. Syarat suatu sengketa dapat diselesaikan melalui arbitrase harus ada klausul arbitrase yang merupakan perjanjian arbitrase yang dibuat oleh para pihak bahwa mereka sepakat sengketanya diselesaikan melalui arbitrase. Perjanjian arbitrase dapat dibuat sebelum atau sesudah terjadinya sengketa. Apabila tidak ada klausul arbitrase maka sengketa tidak dapat diselesaikan melalui arbitrase.

Penyelesaian sengketa melalui arbitrase dilakukan oleh arbiter yang merupakan orang yang ahli dalam bidangnya. Jangka waktu penyelesaian melalui arbitrase adalah 180 hari. Putusan arbitrase bersifat final dan mengikat para pihak dan tidak dapat diajukan upaya hukum banding atau kasasi. Sengketa yang sudah diselesaikan melalui arbitrase tidak dapat lagi untuk diselesaikan melalui pengadilan. Biaya yang dibutuhkan untuk menyelesaikan kasus melalui arbirase lebih mahal, karena sengketa diselesaikan oleh arbiter yang ahli dalam bidangnya. Penyelesaian sengketa melalui arbitrase lebih banyak digunakan oleh pelaku usaha menengah keatas karena mampu membayar biaya proses arbitrase yang mahal.

Keungggulan penyelesaian sengketa melalui arbitrase adalah penyelesaian bersifat tertutup akan menjaga nama baik dari perusahaan, putusannya final dan mengikat para pihak, putusannya lebih tepat karena diselesaikan oleh abiter yang ahli dalam bidangnya. Jangka waku pemeriksaan sudah ditentukan yaitu dalam dalam waktu 180 sejak pendaftaran arbitrase. Hal ini merupakan solusi penyelesaian sengketa di pengadilan yang memakan waktu yang lama dan berlarut-larut. Proses pemeriksaan sengketa tidak terikat kepada aturan yang bersifat formil seperti di pengadilan, para pihak dapat memilih dan menentukan sendiri waktu, tempat dan prosedur penyelesaian asal tidak bertentangan dengan Undang-Undang Nomor 30 Tahun 1999 tentang Alternatif Penyelesaian Sengketa dan Arbitrase.

\section{Kesimpulan}

Setelah dilakukan analisis terhadap rumusan masalah dirumuskan masalah sebagai berikut:

1. Penyelesaian sengketa melalui alternatif penyelesaian sengketa merupakan bentuk penyelesaian sengketa yang dilakukan secara non litigasi yang 
didasarkan kepada itikad baik untuk mencapai kesepakatan. Penyelesaian sengketa lebih bersifat kekeluargaan, mengutamakan musyawarah, penyelesaian secara saling menguntungkan (win-win solution), penyelesaian bersifat sukarela tidak ada unsur paksaan, proses bersifat sederhana, lebih menghemat waktu dan biaya. Hal ini sebagai wujud pelaksanaan asas hukum acara perdata" pemeriksaan sederhana, waktu singkat dan biaya murah.

2. Keunggulan penyelesaian sengketa melalui alternatif penyelesaaan sengketa adalah pemeriksaan dilakukan secara sederhana tidak berbelit-belit, tidak terikat pada suatu aturan yang formal, bersifat sukarela, waktu singkat dan biaya lebih murah. Keputusan yang diambil lebih tepat, dapat mengkafer kepentingan pihak yang bersengketa, pemeriksaan dan putusan bersifat tertutup tidak dipublikasikan dan tidak ada pihak yang kalah dan menang, putusan yang diambil berdasarkan saling menguntungkan (win-win solution).

\section{Saran}

1. Pihak yang bersengketa untuk memilih penyelesaian sengketa melalui alternatif penyelesaian sengketa (non litigasi), karena banyak keunggulankeunggulan yang diperoleh antara lain yaitu pemeriksaan lebih sederhana, waktu singkat dan biaya murah.

2. Untuk mewujudkan penyelesaian sengketa melalui alternatif penyelesaian, maka diperlukan peran aktif para pihak yang didasarkan pada itikad baik. Konsisten untuk menyelesaikan sengketanya melalui alternatif penyelesaian sengketa, sehingga didapat hasil penyelesaian penyelesaian berdasarkan kesepakatan yang memenuhi kebutuhan para pihak secara adil tepat dan memuaskan.

3. Pihak ketiga sebagai mediator, konsliator untuk berperan aktif membantu memberi masukan usulan terhadap masalah yang dihadapi oleh pihak yang bersengketa, sehingga asas hukum acara perdata penyelesaian sengketa sesederhana mungkin, waktu singkat dan biaya murah dapat diwujudkan.

4. Agar penyelesaian sengketa melalui alternatif penyelesaaian sengketa mempunyai kekuatan eksekutorial harus didaftarkan di Pengadilan Negeri dengan mengajukan gugatan.

\section{Referensi:}

Aji, A.M.; Yunus, N.R. Basic Theory of Law and Justice, Jakarta: Jurisprudence Institute, 2018.

Emirzon, Joni. Alternatif Penyelesaian Sengketa di luar Pengadilan: Negosiasi, Mediasi, Konsiliasi dan Arbitrase, PT Gramedia Pustaka Utama, Jakarta.

Hadolf, Huala; \& Chandrawulan, Masalah-Masalah Hukum dalam Perdagangan Internasional, PT Rajagrafindo Persada, Jakarta. 
Harahap, M. Yahya. Beberapa Tinjauan Mengenai Sistem Peradilan dan Penyelesaian Sengketa, PT Citra Aditya Bakti, Bandung, 1997.

http://en.mwikipedia.org/wiki/ conciliation, diakses Kamis tanggal 19 maret 2020, pukul 18.00

Maggalatung, A.S.; Aji, A.M.; Yunus, N.R. How The Law Works, Jakarta: Jurisprudence Institute, 2014.

Margono, Suyud. ADR (Alternative Dispute Resolution) dan Arbitrase), Ghalia Indonesia, 2000.

Marwan, M.; \& P, Jimmy. Kamus Hukum: Dictionary of Law Complete Edition, Reality Publisher, Surabaya, 2009.

Rezki, Annissa; Anggraeni, RR. Dewi; Yunus, Nur Rohim. "Application of Civil Law Theory In the Termination of Custody of Adopted Children in Indonesia," Journal of Legal Research, Volume 1, No. 6 (2019).

Subekti, R; Tjitsudibio, R. Kitab Undang-Undang Hukum Perdata, PT. Prandnya Paramita, Jakarta, 2003.

Tim Penyunting Kamus Hukum Ekonomi ELIPS, Kamus Hukum Ekonomi ELIPS, ELIPS Project, Jakarta

Tim Penyusunan Kamus Pusat Pembinaan dan Pengembangan Bahasa, Kamus Besar Bahasa Indonesia, Departemen Pendidikan Kebudayaan Republik Indonesia, Jakarta, 1988

Umam, Khotibul. Penyelesaian Sengketa diluar Pengadilan, Pustaka Yustisia, Yogyakarta.

Undang-Undang Nomor 30 tahun 1999 tentang Alternatif Penyelesaian Sengketa.

Usman, Rachmadi. Hukum Arbitrase Nasional, PT Gramedia Widiasarana Indonesia, Jakarta, 2002.

Usman, Rachmadi. Pilihan Penyelesaian Sengketa di luar Pengadilan, PT Citra Aditya Bakti, Bandung, 2013.

Widnyata, I. Made. Alternatif Penyelesaian Sengketa dan Arbitrase, Fikahati Aneska, Jakarta, 2014. 


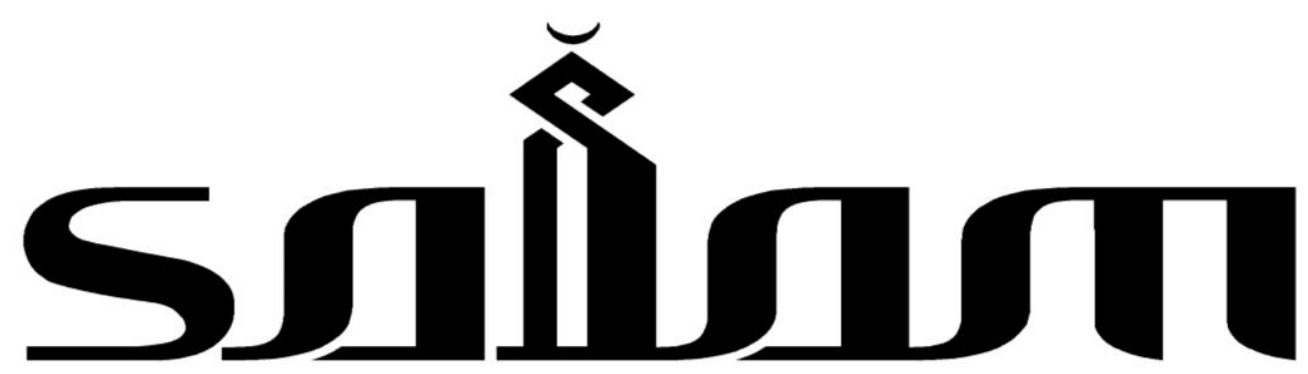

Jumnal Sosial dan Budaya Syar'i

\section{PEDOMAN TEKNIS PENULISAN BERKALA ILMIAH}

1. Artikel adalah benar-benar karya asli penulis, tidak mengandung unsur plagiasi, dan belum pernah dipublikasikan dan/atau sedang dalam proses publikasi pada media lain yang dinyatakan dengan surat pernyataan yang ditandatangani di atas meterai Rp 6000;

2. Naskah dapat berupa konseptual, resume hasil penelitian, atau pemikiran tokoh;

3. Naskah dapat berbahasa Indonesia, Inggris, Arab, maupun bahasa Rusia;

4. Naskah harus memuat informasi keilmuan dalam ranah ilmu hukum Positif;

5. Aturan penulisan adalah sebagai berikut:

a. Judul. Ditulis dengan huruf kapital, maksimum 12 kata diposisikan di tengah (centered);

b. Nama penulis. Ditulis utuh, tanpa gelar, disertai afiliasi kelembagaan dengan alamat lengkap, dan alamat e-mail;

c. Abstrak. Ditulis dalam bahasa Inggris dan Bahasa Indonesia antara 80-120 kata;

d. Sistematika penulisan naskah adalah sebagai berikut:

1) Judul;

2) Nama penulis (tanpa gelar akademik), nama dan alamat afiliasi penulis, dan e-mail;

3) Abstrak ditulis dalam dua bahasa, yaitu bahasa Indonesia dan Inggris, antara 80-120 kata;

4) Kata-kata kunci, antara 2-5 konsep yang mencerminkan substansi artikel;

5) Pendahuluan;

6) Sub judul (sesuai dengan keperluan pembahasan);

7) Penutup; dan

8) Pustaka Acuan (hanya memuat sumber-sumber yang dirujuk dan sedapat mungkin terbitan 10 tahun terakhir).

e. Ukuran kertas yang digunakan adalah kertas HVS 70 gram, ukuran A4, margin: atas $3,5 \mathrm{~cm}$, bawah $3.5 \mathrm{~cm}$, kiri $3,5 \mathrm{~cm}$, dan kanan $3,5 \mathrm{~cm}$;

f. Panjang Naskah antara 13 s.d. 15 halaman, spasi 1, huruf Palatino, ukuran 11;

g. Pengutipan kalimat. Kutipan kalimat ditulis secara langsung apabila lebih dari empat baris dipisahkan dari teks dengan jarak satu spasi dengan ukuran huruf 10 point. Sedangkan kutipan kurang dari empat baris diintegrasikan dalam teks, dengan tanda apostrof ganda di awal dan di akhir kutipan. Setiap kutipan diberi nomor. Sistem pengutipan adalah footnote (bukan bodynote atau endnote). Penulisan footnote menggunakan sistem turabian. Setiap artikel, buku, dan sumber lainnya yang dikutip harus tercantum dalam pustaka acuan;

h. Pengutipan Ayat Alquran dan Hadis. Ayat yang dikutip menyertakan keterangan ayat dalam kurung, dengan menyebut nama surah, nomor surah, dan nomor ayat, seperti (Q.s. al-Mu'min [40]: 43). Pengutipan Hadis menyebutkan nama perawi (H.r. al-Bukhārĩ dan Muslim) ditambah referensi versi cetak kitab Hadis yang dikutip. Hadis harus dikutip dari kitab-kitab Hadis standar (Kutub al-Tis'ah);

i. Cara pembuatan footnote. Footnote ditulis dengan font Palation size 9, untuk pelbagai sumber, antara lain: 
1) Buku: nama utuh penulis (tanpa gelar), judul buku (tempat terbit: penerbit, tahun terbit), cetakan, volume, juz, halaman. Contoh: Soerjono Soekanto, Pokok-pokok Sosiologi Hukum, (Jakarta: Rajawali Pers, 1986), h. 10.

2) Buku terjemahan, contoh: Roscoe Pound, Pengantar Filsafat Hukum: Buku III, diterjemahkan oleh Moh. Radjab, (Jakarta: Bharata, 1963), h. 15;

1) Jurnal, contoh: Nur Rohim, "Kontroversi Pembentukan Perppu No. 1 Tahun 2013 tentang mahkamah konstitusi dalam ranah kegentingan yang memaksa", dalam Jurnal Cita Hukum, Vol. 2, No. 1 (2014), h. 157.

2) Artikel sebagai bagian dari buku (antologi), contoh: Hikmahanto Juwana, "Penegakan Hukum dalam Kajian Law and Development: Problem dan Fundamen bagi Solusi Indonesia", dalam Muhammad Tahir Azhary, Beberapa Aspek Hukum Tata Negara, Hukum Pidana, dan Hukum Islam, (Jakarta: Kencana Prenada Media Gorup, 2012), h. 127.

3) Artikel dari internet, contoh: Ahmad Tholabi Kharlie, "Problem Yuridis RUU Syariah" dalam http://ahmadtholabi.com/2008/03/03/problem-yuridis-ruu-syariah, diunduh pada 20 Maret 2012.

4) Artikel dari majalah, contoh: Susilaningtias, "Potret Hukum Adat pada Masa Kolonial", dalam Forum Keadilan, No. 17, 20 Agustus 2006.

5) Makalah dalam seminar, contoh: Jimly Asshiddiqie, "Kedudukan Mahkamah Konstitusi dalam Struktur Ketatanegaraan Indonesia", Makalah disampaikan dalam Kuliah Umum Fakultas Hukum Universitas Sebelas Maret, Surakarta, pada 2 Maret 2004.

j. Pustaka Acuan: daftar pustaka acuan ditulis sesuai urutan abjad, nama akhir penulis diletakkan di depan. Contoh:

1) Buku, contoh: Soekanto, Soerjono, Pokok-pokok Sosiologi Hukum, Jakarta: Rajawali Pers, 1986.

2) Buku terjemahan, contoh: Pound, Roscoe, Pengantar Filsafat Hukum: Buku III, diterjemahakan oleh Moh. Radjab, Jakarta: Bharata, 1963.

3) Jurnal, contoh: Rohim, Nur, "Kontroversi Pembentukan Perppu No. 1 Tahun 2013 tentang mahkamah konstitusi dalam ranah kegentingan yang memaksa", dalam Jurnal Cita Hukum, Vol. 2, No. 1 (2014).

4) Artikel sebagai bagian dari buku, contoh: Juwana, Hikmahanto, "Penegakan Hukum dalam Kajian Law and Development: Problem dan Fundamen bagi Solusi Indonesia", dalam Muhammad Tahir Azhary, Beberapa Aspek Hukum Tata Negara, Hukum Pidana, dan Hukum Islam, Jakarta: Kencana Prenada Media Gorup, 2012.

5) Artikel yang dikutip dari internet, contoh: Kharlie, Ahmad Tholabi, "Problem Yuridis RUU Syariah" dalam http://ahmadtholabi.com/2008/03/03/problem-yuridis-ruu-syariah, diunduh pada 20 Maret 2012.

6) Majalah, contoh: Susilaningtias, "Potret Hukum Adat pada Masa Kolonial", dalam Forum Keadilan, No. 17, 20 Agustus 2006.

7) Makalah dalam seminar, contoh: Asshiddiqie, Jimly, "Kedudukan Mahkamah Konstitusi dalam Struktur Ketatanegaraan Indonesia", Makalah disampaikan dalam Kuliah Umum Fakultas Hukum Universitas Sebelas Maret, Surakarta, pada 2 Maret 2004.

k. Penutup: artikel ditutup dengan kesimpulan;

I. Biografi singkat: biografi penulis mengandung unsur nama (lengkap dengan gelar akademik), tempat tugas, riwayat pendidikan formal (S1, S2, S3), dan bidang keahlian akademik;

6. Setiap naskah yang tidak mengindahkan pedoman penulisan ini akan dikembalikan kepada penulisnya untuk diperbaiki.

7. Naskah sudah diserahkan kepada penyunting, selambat-lambatnya tiga bulan sebelum waktu penerbitan (April, Agustus. dan Desember) dengan mengupload pada laman OJS jurnal pada alamat http://journal.uinjkt.ac.id/index.php/salam atau dikirim langsung via e-mail ke: jurnal.salam@gmail.com atau nurrohimyunus@uinjkt.ac.id..] 


\section{Indexed by :}
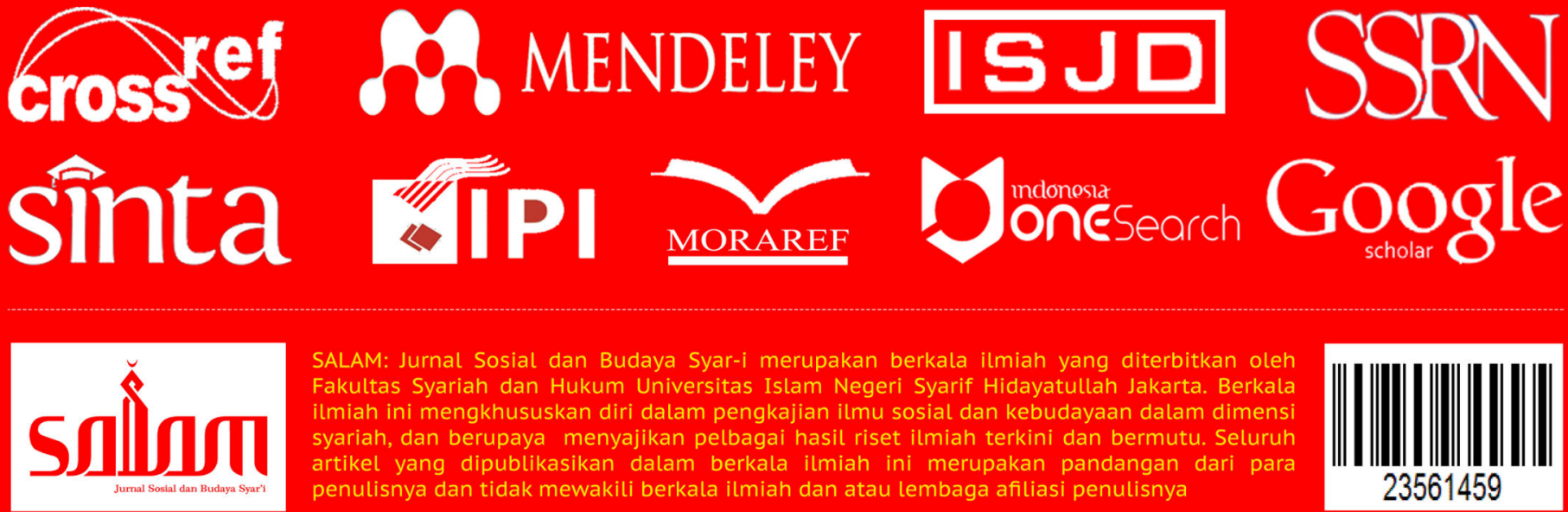

SALAM: Jurnal Sosial dan Budaya Syar-i merupakan berkala ilmiah yang diterbitkan oleh Fakultas Syariah dan Hukum Universitas Islam Negeri Syarif Hidayatullah Jakarta. Berkala ilmiah ini mengkhususkan diri dalam pengkajian ilmu sosial dan kebudayaan dalam dimensi syariah, dan berupaya menyajikan pelbagai hasil riset ilmiah terkini dan bermutu. Seluruh artikel yang dipublikasikan dalam berkala ilmiah ini merupakan pandangan dari para penulisnya dan tidak mewakili berkala ilmiah dan atau lembaga afiliasi penulisnya

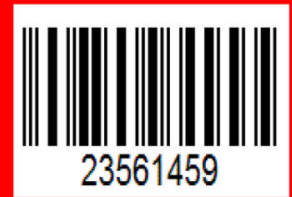

